\title{
THE AIR QUALITY ASSESSMENT FROM THE STATIONARY Source Air Pollution
}

\author{
Miriam Andrejiova $^{\mathrm{a}}$, Ruzena Kralikova ${ }^{\mathrm{a}}$, Emil Wessely $^{\mathrm{b}}$ \\ ${ }^{a}$ Technical University of Kosice,Faculty of Mechanical Engineering, Letna 9, 04001 Kosice, Slovakia \\ ${ }^{b}$ Pod Kastielom 11, 04021 Kosice, Slovakia
}

\begin{abstract}
Air quality significantly affects the state of the environment, human health, as well as individual ecosystems. This contribution deals with the assessment of air quality from big stationary source located in Eastern Slovakia. Our additional aim was to define the final order of the air pollution in selected monitored areas based on the level of air polluted by surveyed contamination substances. To analyze the state of air pollution in the area of the selected source pollution, we used basic statistical methods and methods of multidimensional comparison.
\end{abstract}

Keywords: pollutants; air pollution; air quality state; emissions; statistical methods
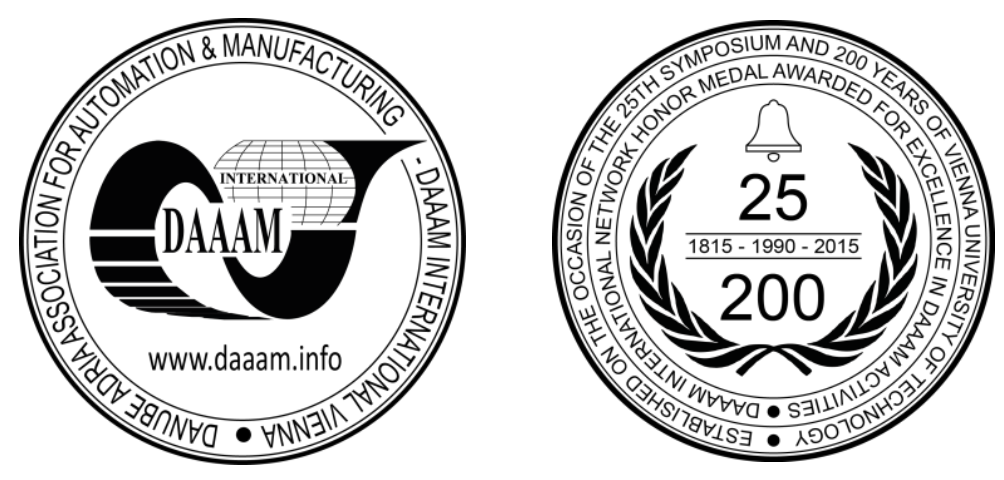

This Publication has to be referred as: Andrejiova, M[iriam]; Kralikova, R[uzena] \& Wessely, E[mil] (2016). The Air Quality Assessment from the Stationary Source Air Pollution, Proceedings of the 26th DAAAM International Symposium, pp.0082-0088, B. Katalinic (Ed.), Published by DAAAM International, ISBN 978-3-902734-07-5, ISSN 1726-9679, Vienna, Austria DOI:10.2507/26th.daaam.proceedings.012 


\section{Introduction}

Air pollution is a phenomenon that increased both in geographical and temporal measure since the start of the civilisation. It is therefore a complex problem that covers many subjects. Air pollution impacts various scales ranging from pure local over regional to global. Cities are by nature concentrations of humans, materials and activities. Today nitrogen oxides, hydrocarbons and small particles attract the attention. Most important are health impacts and impacts on vegetation, on natural and agricultural ecosystems in the form of acidification and eutrophication and impacts of ozone. The depletion of the ozone layer and the increasing greenhouse effect are two most important environmental problems [1].

At present several hundreds of air contamination substances are known and identifiable. The most frequently monitored contamination substances are represented by the substances resulting from combustion of solid, liquid and gaseous fuels as the: carbon oxide, sulphur dioxide, oxides of nitrogen including nitrogen dioxide and nitrogen oxide, the dust components and the secondary pollution substances like the ozone, carbon dioxide and other [2, 3, 4]. The particulate matter (PM) represent the most important health risk involved in air contamination within EU [3, 5, 6]. According to World Health Organization (WHO) reference values, more severe than EU legislative limits, $81 \%$ resp. $95 \%$ of the cities inhabitants were exposed to PM concentrations exceeding the reference values specified with regard to the human health prevention. The ozone may evoke the respiratory problems and may cause the premature death. 17 $\%$ of the inhabitants were exposed to the concentrations exceeding the EU target value of the ozone [5, 7, 8]. The formation of both the solid substances and the ozone is contributed by the nitrogen oxide (NO2) mainly reasoning the eutrophication - the overgrowth of the water plants and sea-grass and the acidification. In many countries of the Union the inland nitrogen oxides emissions remain over the upper levels specified in EU legal enactments and in the international agreements. A big success was reached regarding the sulphur dioxide (SO2) - its emissions markedly decreased during the foregoing years. The EU legal enactments demand the application of the exhaust gas filtration technologies and the fuel of the lower sulphur volume. In EU the air concentrations of the carbon monoxide, benzene and of the heavy metals (arsenic, cadmium, nickel and plumbum) are generally low, local and sporadic. The cases of both the exceeded limits and the target values specified by EU legal enactments are rare.

In Slovakia, several years of observations result in the investigation that the emissions of both the solid substances and the sulphur dioxide are continuously decreasing from 1990 and that it is caused also by the changed fuel basis in favour of the generous fuels, through the implementation of the separators technique and by improving its efficiency, through the application of the heating oils with low volume of the sulphur and by installation of the desulphurating equipment in big energetic sources. $\mathrm{CO}$ emissions are of the decreasing tendencies too. The nitrogen oxides emissions show slight decrease from 1990 [3, 5, 9]. The air prevention is one of the most monitored environmental components evidenced through a considerable progress of the development of the legislation. Now, in Slovakia the allowed level of air pollution is determined by Law No. 318/2012 Coll. of Laws on the Air [10] and by Ministry of Environment Regulation No. 442/2013 Coll. of Laws on the Air Quality Limit Values, tolerance limits, numbers of exceeded limit values [11]. Long term, within several spheres, Slovakia does not follow the limit values of dust particles (PM10) specified through the European Parliament and Board Directive 2008/50/ES on Environment Air Quality and on Clean Air transposed to Ministry of Environment Regulation No. 442/2013 Coll. of Laws on Air Quality [12].

\section{Object and methods of research}

In east Slovakia the air quality is to a great degree influenced by the activities of big stationary industrial sources within both the metallurgical and the chemical industries and through the production of heat and electric energy. The considerable pollution of the emissions negatively impacting the air quality is the consequence of the mentioned activities [13].

\begin{tabular}{ll}
\hline Monitoring area & Distance from contamination source $(\mathrm{km})$ \\
\hline MA1 & 8 \\
MA2 & 5.6 \\
MA3 & 15.8 \\
MA4 & 10.3 \\
MA5 & 1 \\
\hline
\end{tabular}

Table 1. Monitoring areas - characteristics

In East Slovakia is located an important steel plant which, on one hand, is one of the biggest and the most important companies of decisive relevance regarding entire Slovakia, but on the other hand it is one of big air polluters. With more than $10 \%$ share of SO2 production it is one of four dominant SO2 production sources within Slovakia.

One of many obligations of the air pollution sources operators is their responsibility to perform the regular monitoring of the particular polluting substances discharged from these sources. The purpose is to recognize the 
compliance with the specified emission limits. The steel plant performs also the regular air monitoring by the measuring vehicle in surrounding villages. In recent time period the most frequently monitored areas were the five villages: MA1, MA2, MA3, MA4 and MA5 (Table 1). Every month is realized the distribution and the collection of the dust fall sample-cases within the localities near the company namely due to the long-term control of the spread and the evaluation of the soil dustiness intensity.

To analyze the state of air pollution in the area of the selected source pollution, we used basic statistical methods and methods of multidimensional comparison.

\section{Result}

The level of the air quality of selected areas within the strategic plant environment was described by five contamination substances: carbon oxide $\mathrm{CO}$, sulphur dioxide $\mathrm{SO}_{2}$, nitrogen oxide $\mathrm{NO}_{2}$, ozone $\mathrm{O}_{3}$ and the particulate matter $\mathrm{PM}_{10}$. The air quality assurance was based on the previous year data measured by the company.

\subsection{Basic characteristic}

The Table 2 shows the basic features of selected air quality indicators within the respective locations. The values of $\mathrm{CO}$ and $\mathrm{O}_{3}$ represent the maximum 8-hour day average. The values of $\mathrm{SO}_{2}$ and $\mathrm{PM}_{10}$ show the 24-hour average and the values of $\mathrm{NO}_{2}$ represent the maximum 1 hour average.

\begin{tabular}{|c|c|c|c|c|c|c|}
\hline \multirow{2}{*}{$\begin{array}{l}\text { Monitoring } \\
\text { area }\end{array}$} & Max. daily & $\mathrm{CO}\left(\mathrm{mg} / \mathrm{m}^{3}\right)$ & $\mathrm{SO}_{2}\left(\mu \mathrm{g} / \mathrm{m}^{3}\right)$ & $\mathrm{NO}_{2}\left(\mu \mathrm{g} / \mathrm{m}^{3}\right)$ & $\mathrm{O}_{3}\left(\mu \mathrm{g} / \mathrm{m}^{3}\right)$ & $\mathrm{PM}_{10}\left(\mu \mathrm{g} / \mathrm{m}^{3}\right)$ \\
\hline & average & 8-hours & 24-hours & 1-hour & 8-hours & 24-hours \\
\hline \multirow[t]{3}{*}{ MA1 } & Average & 0.935 & 32.955 & 18.227 & \multirow{3}{*}{$\begin{array}{l}88.750 \\
5.560 \\
94-83\end{array}$} & 21.909 \\
\hline & Stand.deviation & 0.388 & 16.102 & 16.142 & & 10.034 \\
\hline & Max-min & $1.4-0.1$ & $55-1$ & $59-1$ & & $39-5$ \\
\hline \multirow[t]{3}{*}{ MA2 } & Average & 1.217 & 39.087 & 38.130 & 63.625 & 33.529 \\
\hline & Stand.deviation & 0.402 & 15.719 & 18.013 & 21.974 & 14.803 \\
\hline & Max-min & $1.9-0.1$ & $65-14$ & $72-7$ & $94-41$ & $60-6$ \\
\hline \multirow[t]{3}{*}{ MA3 } & Average & 1.184 & 33.429 & 31.611 & 60.222 & 32.273 \\
\hline & Stand.deviation & 0.456 & 13.815 & 21.219 & 5.674 & 9.328 \\
\hline & Max-min & $2.3-0.6$ & $48-4$ & $85-3$ & $69-50$ & $45-13$ \\
\hline \multirow[t]{3}{*}{ MA4 } & Average & 1.263 & 52.745 & 33.340 & 75.333 & 22,042 \\
\hline & Stand.deviation & 0.539 & 33.966 & 21.379 & 24.055 & 7.850 \\
\hline & Max-min & $2.5-0.3$ & $230-8$ & $85-5$ & $91-27$ & $43-12$ \\
\hline \multirow[t]{3}{*}{ MA5 } & Average & 0.981 & 27.714 & 30.434 & 28.250 & 27.375 \\
\hline & Stand.deviation & 0.389 & 10.199 & 15.496 & 7.365 & 17.378 \\
\hline & Max-min & $1.7-0.4$ & $48-4$ & $55-6$ & $37-19$ & $51-11$ \\
\hline limit & & $10 \mathrm{mg} / \mathrm{m}^{3}$ & $125 \mu \mathrm{g} / \mathrm{m}^{3}$ & $200 \mu \mathrm{mg} / \mathrm{m}^{3}$ & $120 \mu \mathrm{g} / \mathrm{m}^{3}$ & $50 \mu \mathrm{g} / \mathrm{m}^{3}$ \\
\hline
\end{tabular}

Table 2. Descriptive characteristics of air quality indicators

$\mathrm{CO}$ concentrations found within the respective measuring locations result in the knowledge that the monitoring area MA4 is the most contaminated locality. The order of the locations of the highest average CO concentration is as follows: MA4 > MA2 > MA3 > MA5 > MA1.

The maximum daily 1-hour $\mathrm{SO}_{2}$ value was measured in the monitoring locality MA4 $\left(230 \mu \mathrm{m} / \mathrm{m}^{3}\right)$. The order of the locations of the highest average of $\mathrm{SO}_{2}$ concentrations is as follows: MA4 > MA2 > MA3 > MA1 > MA5.

During the existing time period the highest average $\mathrm{NO}_{2}$ value was measured in the monitoring location MA4. The order of the locations of the highest average $\mathrm{NO}_{2}$ concentration is as follows: MA2 > MA4 > MA3 > MA5 > MA1.

In the monitoring location MA1 the highest average value of ozone $\mathrm{O}_{3}$, of allowed limit $120 \mu \mathrm{m} / \mathrm{m}^{3}$, was measured during the time period of the monitoring. The order of the locations of the highest $\mathrm{O}_{3}$ concentration is as follows: MA1 $>$ MA4 > MA2> MA3> MA5.

The highest $\mathrm{PM}_{10}$ value was measured in the monitoring location MA2 representing 1.2 multiple of allowed 50 $\mu \mathrm{m} / \mathrm{m}^{3}$ limit value. The order of the locations air pollution is as follows: MA2 > MA3 > MA5 > MA4 > MA1. Air Quality Index (AQI) was applied in air quality assessmen (Table 3) [14]. The measured data analysis most frequently shows the low level of air polluted by surveyed indicators in respective monitoring locations (Table 4). 


\begin{tabular}{llllll}
\hline \hline 26TH DAAAM INTERNATIONAL SYMPOSIUM ON INTELLIGENT MANUFACTURING AND AUTOMATION \\
\hline \hline \multicolumn{7}{l}{$\begin{array}{l}\mathrm{CO}(8 \mathrm{~h}) \\
\left(\mathrm{mg} / \mathrm{m}^{3}\right)\end{array}$} & $\begin{array}{l}\mathrm{SO}_{2}(24 \mathrm{~h}) \\
\left(\mu \mathrm{g} / \mathrm{m}^{3}\right)\end{array}$ & $\begin{array}{l}\mathrm{NO}_{2}(1 \mathrm{~h}) \\
\left(\mu \mathrm{g} / \mathrm{m}^{3}\right)\end{array}$ & $\begin{array}{l}\mathrm{O}_{3}(8 \mathrm{~h}) \\
\left(\mu \mathrm{g} / \mathrm{m}^{3}\right)\end{array}$ & $\begin{array}{l}\mathrm{PM}_{10}(24 \mathrm{~h}) \\
\left(\mu \mathrm{g} / \mathrm{m}^{3}\right)\end{array}$ \\
\hline Pollution category & $15.5-30$ & $500-1000$ & $950-1900$ & $223-500$ & $238-500$ \\
Unhealthy & $11.6-15.5$ & $250-500$ & $400-950$ & $180-223$ & $144-238$ \\
Moderate pollution & $10-11.6$ & $125-500$ & $200-400$ & $120-180$ & $50-144$ \\
Low pollution & $4-10$ & $20-125$ & $40-200$ & $65-120$ & $20-50$ \\
Good quality & $0-4$ & $0-20$ & $0-40$ & $0-65$ & $0-20$ \\
\hline
\end{tabular}

Table 3. Breakpoints for the AQI, according to [14]

\begin{tabular}{llllll}
\hline $\begin{array}{l}\text { Monitoring } \\
\text { area }\end{array}$ & $\begin{array}{l}\mathrm{CO}(8 \mathrm{~h}) \\
\left(\mathrm{mg} / \mathrm{m}^{3}\right)\end{array}$ & $\begin{array}{l}\mathrm{SO}_{2}(24 \mathrm{~h}) \\
\left(\mu \mathrm{g} / \mathrm{m}^{3}\right)\end{array}$ & $\begin{array}{l}\mathrm{NO}_{2}(1 \mathrm{~h}) \\
\left(\mu \mathrm{g} / \mathrm{m}^{3}\right)\end{array}$ & $\begin{array}{l}\mathrm{O}_{3}(8 \mathrm{~h}) \\
\left(\mu \mathrm{g} / \mathrm{m}^{3}\right)\end{array}$ & $\begin{array}{l}\mathrm{PM}_{10}(24 \mathrm{~h}) \\
\left(\mu \mathrm{g} / \mathrm{m}^{3}\right)\end{array}$ \\
\hline MA1 & Good quality & Low pollution & Low pollution & Low pollution & Low pollution \\
MA2 & Good quality & Low pollution & Low pollution & Low pollution & Moderate pollution \\
MA3 & Good quality & Low pollution & Low pollution & Low pollution & Low pollution \\
MA4 & Good quality & Low pollution & Low pollution & Low pollution & Low pollution \\
MA5 & Good quality & Low pollution & Low pollution & Good quality & Low pollution \\
\hline
\end{tabular}

Table 4. AQI of surveyed indicators in respective monitoring locations.

\subsection{Multidimensional comparison methods}

Our additional aim is to define the final order of the air pollution in selected monitoring localities based on the level of air polluted by surveyed contamination substances. In comparison of monitoring areas were chosen the methods: simple ordering method, the scoring method, the standardized variable method and the fictitious point distance method $[15,16,17,18]$. All variables are deemed as de-stimulating variables (its decrease is the positive effect).

Through the ordering method the location of the lowest average value of surveyed parameter was assigned with the highest value equal to 1 . In case of the equal values the respective monitoring locations were assigned with average order. The final order of surveyed locations was determined based on the sum of the respective orders. The location of the lowest sum of orders is assigned with the lowest order. The analysis indicates that locality MA2 is the monitoring location of the highest concentration of air pollution substances and locality MA5 is the location of the lowest concentration (Table 5). The final order is as follows: MA2 > MA4 > MA3 > MA1 > MA5.

\begin{tabular}{llllllll}
\hline $\begin{array}{l}\text { Monitoring } \\
\text { area }\end{array}$ & $\begin{array}{l}\mathrm{CO}(8 \mathrm{~h}) \\
\left(\mathrm{mg} / \mathrm{m}^{3}\right)\end{array}$ & $\begin{array}{l}\mathrm{SO}_{2}(24 \mathrm{~h}) \\
\left(\mu \mathrm{g} / \mathrm{m}^{3}\right)\end{array}$ & $\begin{array}{l}\mathrm{NO}_{2}(1 \mathrm{~h}) \\
\left(\mu \mathrm{g} / \mathrm{m}^{3}\right)\end{array}$ & $\begin{array}{l}\mathrm{O}_{3}(8 \mathrm{~h}) \\
\left(\mu \mathrm{g} / \mathrm{m}^{3}\right)\end{array}$ & $\begin{array}{l}\mathrm{PM}_{10}(24 \mathrm{~h}) \\
\left(\mu \mathrm{g} / \mathrm{m}^{3}\right)\end{array}$ & $\mathrm{d}_{\mathrm{i}}$ & Order \\
\hline MA1 & 1 & 2 & 1 & 5 & 1 & 10 & 2. \\
MA2 & 4 & 4 & 5 & 3 & 5 & 21 & 5. \\
MA3 & 3 & 3 & 3 & 2 & 4 & 15 & 3. \\
MA4 & 5 & 5 & 4 & 4 & 2 & 20 & 4. \\
MA5 & 2 & 1 & 2 & 1 & 3 & 9 & 1. \\
\hline
\end{tabular}

Table 5. The resulting values and average order - Ordering method

With the scoring method the determined values of variables were replaced with the number of points. Maximum number of 100 points was assigned to the location of the lowest value of given parameter. Remaining monitoring locations were assigned with the number of points according to formula:

$z_{i j}=\frac{x_{\min , j}}{x_{i j}} .100 \%, i=1,2, \ldots .5, j=1,2, \ldots 5$

where $i$ is the number of monitoring locations, $j$ is the number of variables, $b_{i j}$ is the number of points of $j$ variable in $i$ measuring location, $x_{i j}$ is the value of assigned variable $d_{i}$ appertaining to $i$ location and $x_{\min , j}$ is the minimum value of the respective variable.

Based on the total score is defined the order of the respective monitoring locations. The final order of the monitoring locations is as follows (Table 6): MA2 > MA4 > MA3 > MA1 > MA5. 


\begin{tabular}{llllllll}
\hline $\begin{array}{l}\text { Monitoring } \\
\text { area }\end{array}$ & $\begin{array}{l}\mathrm{CO}(8 \mathrm{~h}) \\
\left(\mathrm{mg} / \mathrm{m}^{3}\right)\end{array}$ & $\begin{array}{l}\mathrm{SO}_{2}(24 \mathrm{~h}) \\
\left(\mu \mathrm{g} / \mathrm{m}^{3}\right)\end{array}$ & $\begin{array}{l}\mathrm{NO}_{2}(1 \mathrm{~h}) \\
\left(\mu \mathrm{g} / \mathrm{m}^{3}\right)\end{array}$ & $\begin{array}{l}\mathrm{O}_{3}(8 \mathrm{~h}) \\
\left(\mu \mathrm{g} / \mathrm{m}^{3}\right)\end{array}$ & $\begin{array}{l}\mathrm{PM}_{10}(24 \mathrm{~h}) \\
\left(\mu \mathrm{g} / \mathrm{m}^{3}\right)\end{array}$ & $\mathrm{d}_{\mathrm{i}}$ & Order \\
\hline MA1 & 100.000 & 84.099 & 100.000 & 31.831 & 100.000 & 83.186 & 2. \\
MA2 & 76.804 & 70.904 & 47.802 & 44.401 & 65.343 & 61.051 & 5. \\
MA3 & 78.956 & 82.906 & 57.661 & 46.910 & 67.887 & 66.864 & 3. \\
MA4 & 74.038 & 52.544 & 54.671 & 37.500 & 99.399 & 63.630 & 4. \\
MA5 & 95.316 & 100.000 & 59.884 & 100.000 & 80.033 & 87.047 & 1. \\
\hline
\end{tabular}

Table 6. The resulting values and average order - Scoring method

In the standardized variable method are the values of de-stimulating variables standardized according to the relation:

$z_{i j}=\frac{\bar{x}_{j}-x_{i j}}{s_{j}}, i=1,2, \ldots 5, j=1,2, \ldots 5$

where $\bar{x}_{j}$ is arithmetic mean and $s_{j}$ is standard deviation of $\mathrm{j}$ variable.

Based on the arithmetic mean of $\bar{z}_{i}$ standardized values was determined the order of the monitoring locations depending on the air pollution. The final order of the monitoring locations is as follows (Table 7): MA2 > MA4 > MA3 $>$ MA1 > MA5.

\begin{tabular}{llllllll}
\hline $\begin{array}{l}\text { Monitoring } \\
\text { area }\end{array}$ & $\begin{array}{l}\mathrm{CO}(8 \mathrm{~h}) \\
\left(\mathrm{mg} / \mathrm{m}^{3}\right)\end{array}$ & $\begin{array}{l}\mathrm{SO}_{2}(24 \mathrm{~h}) \\
\left(\mu \mathrm{g} / \mathrm{m}^{3}\right)\end{array}$ & $\begin{array}{l}\mathrm{NO}_{2}(1 \mathrm{~h}) \\
\left(\mu \mathrm{g} / \mathrm{m}^{3}\right)\end{array}$ & $\begin{array}{l}\mathrm{O}_{3}(8 \mathrm{~h}) \\
\left(\mu \mathrm{g} / \mathrm{m}^{3}\right)\end{array}$ & $\begin{array}{l}\mathrm{PM}_{10}(24 \mathrm{~h}) \\
\left(\mu \mathrm{g} / \mathrm{m}^{3}\right)\end{array}$ & $\mathrm{d}_{\mathrm{i}}$ & Order \\
\hline MA1 & 1.224 & 0.441 & 1.642 & -1.132 & 1.006 & 0.636 & 2. \\
MA2 & -0.685 & -0.198 & -1.054 & -0.017 & -1.114 & -0.614 & 5. \\
MA3 & -0.461 & 0.392 & -0.171 & 0.134 & -0.884 & -0.198 & 3. \\
MA4 & -0.992 & -1.623 & -0.405 & -0.537 & 0.982 & -0.515 & 4. \\
MA5 & 0.914 & 0.988 & -0.012 & 1.553 & 0.009 & 0.690 & 1. \\
\hline
\end{tabular}

Table 7. The resulting values and average order - Standardized variable method

In the fictitious point distance method was defined the fictitious point with the co-ordinates depending on the type of the variable. For de-stimulating variable is formula:

$z_{o j}=\min _{i}\left\{z_{i j}\right\}, i=1,2, \ldots 5$,

where $z_{i j}$ are the standardized values of the variables. The order of the locations was specified through the average

Euclidian fictitious point distance $d_{i}$ according to formula:

$d_{i}=\sqrt{\frac{1}{k} \sum_{i=1}^{k}\left(z_{i j}-z_{o j}\right)^{2}}, i=1,2, \ldots .5$,

The final order of the monitoring locations is as follows (Table 8): MA2 > MA4 > MA3 > MA5 > MA1.

\begin{tabular}{llllllll}
\hline $\begin{array}{l}\text { Monitoring } \\
\text { area }\end{array}$ & $\begin{array}{l}\mathrm{CO}(8 \mathrm{~h}) \\
\left(\mathrm{mg} / \mathrm{m}^{3}\right)\end{array}$ & $\begin{array}{l}\mathrm{SO}_{2}(24 \mathrm{~h}) \\
\left(\mu \mathrm{g} / \mathrm{m}^{3}\right)\end{array}$ & $\begin{array}{l}\mathrm{NO}_{2}(1 \mathrm{~h}) \\
\left(\mu \mathrm{g} / \mathrm{m}^{3}\right)\end{array}$ & $\begin{array}{l}\mathrm{O}_{3}(8 \mathrm{~h}) \\
\left(\mu \mathrm{g} / \mathrm{m}^{3}\right)\end{array}$ & $\begin{array}{l}\mathrm{PM}_{10}(24 \mathrm{~h}) \\
\left(\mu \mathrm{g} / \mathrm{m}^{3}\right)\end{array}$ & $\mathrm{d}_{\mathrm{i}}$ & Order \\
\hline MA1 & 4.914 & 4.264 & 7.267 & 0.000 & 4.495 & 4.188 & 1. \\
MA2 & 0.094 & 2.031 & 0.000 & 1.244 & 0.000 & 0.674 & 5. \\
MA3 & 0.283 & 4.062 & 0.780 & 1.603 & 0.053 & 1.356 & 3. \\
MA4 & 0.000 & 0.000 & 0.421 & 0.355 & 4.393 & 1.034 & 4. \\
MA5 & 3.633 & 6.821 & 1.086 & 7.210 & 1.261 & 4.002 & 2. \\
\hline
\end{tabular}

Table 8 . The resulting values and average order - Fictitious point distance method 
Overall analysis of the air pollution assessment indicates the order of the monitoring locations as follows in Table 9.

\begin{tabular}{lllll}
\hline Ordering method & Scoring method & Standardized variable & Fictitious point distance method & Final order \\
\hline MA2 & MA2 & MA2 & MA2 & 5. \\
MA4 & MA4 & MA4 & MA4 & 4. \\
MA3 & MA3 & MA3 & MA3 & 3. \\
MA1 & MA1 & MA5 & 2. \\
MA5 & MA1 & MA1 & 1. \\
\hline
\end{tabular}

Table 9. Final order of monitoring locations- from locality of the highest level of pollution

Any applied method indicates that the locality MA2 is the location of the highest air pollution. Next are the localities MA4, MA3 and MA1. The monitoring area MA5 seems to be the location of the lowest level of the air pollution. The final order of the monitoring locations is as follows: MA2 > MA4 > MA3 > MA1 > MA5.

Equal orders were verified by Kendall coefficient of concordance $W$. Regarding the concerned case the coefficient of concordance value is $W=0.963$ and indicates a good concordance of the respective methods results. The statistical significance of Kendall coefficient of concordance was confirmed through the table of critical values of real distribution of $w$ parameter.

\section{Conclusion}

High priority recommendations are made in the following six strategic areas: observations, data, understanding, modelling, tools and education. These include the need for more operational urban measurement stations and networks; for an international data archive to aid translation of research findings into design tools, along with guidelines for different climate zones and land uses; to develop methods to analyse atmospheric data measured above complex urban surfaces; to improve short-range, high-resolution numerical prediction of weather, air quality and chemical dispersion through improved modelling of the biogeophysical features of the urban land surface; to improve education about urban meteorology; and to encourage communication across scientific disciplines at a range of spatial and temporal scales. There need reviews with attention to sustainability of cities, applications that use climate information, and scientific understanding in relation to measurements and modelling $[16,19]$.

These are reviewed here with attention to sustainability of cities, applications that use climate information, and scientific understanding in relation to measurements and modelling. Based on the comparison of the measuring locations within the plant environment we found that the highest pollution was in the monitoring locality MA2 and the lowest pollution was in the locality MA5. Surprising is that the pollution source nearest locality MA5 is the locality of the best air quality state. The reason may be the appropriate meteorological conditions and especially the speed and the direction of the wind.

As the Eurobarometer enquiry shows the European citizens see the air pollution very serious. The air pollution across the continent shortens the age of life and lot of people suffer from chronic respiratory diseases. European Commission was interested in the most effective methods of problems solving according to the citizens opinion. The most frequent answer in Slovakia (43\%) and in EU average (38\%) represented the application of more strict air pollution control of industrial technologies and the energy production.

This work is devoted to a statistical analysis of air pollution emissions and air quality assessment from the stationary source. From these results we can deduce the necessity of the research and studies addressing to implementation and development cleaner technologies and techniques (BAT) and integrated control of pollution, because the issue of environmental protection will always be a priority problem.

\section{Acknowledgements}

The work presented in this paper was supported by the Project APVV 0432-12.

\section{References}

[1] W. Guo, X. Liu, Z. Liu, G. Li, Pollution and potential ecological risk evaluation of heavy metals in the sediments around Dongjiang Harbor, Tianjin (2010) Procedia Environmental Sciences, 2, pp. 729-736.

[2] J. Fenger, J. Ch. Tjell, Air Pollution: From a Local to a Global Perspective Royal Society of Chemistry, RSC Publishing, 488 p. 2009.

[3] R. Kralikova, M. Rovnak, M. Kralik, Visualization of environmental data, in: 8th International Scientific Conference on Modern Management of Mine Producing, Geology and Environmental Protection, SGEM, 2 (2008) $577-584$. 
[4] C.M. Kendrick, P. Koonce, L. A. George, Diurnal and seasonal variations of NO, NO2 and PM2.5 mass as a function of traffic volumes alongside an urban arterial, Atmospheric Environment, 122(2015) 133-141.

[5] M. Demo, O. Hronec, M. Tothova et all, Sustainable development, Living within the carrying capacity of biosphere (in Slovak), SPU Nitra, 2007.

[6] M.C. Minguillón, E. Monfort, A. Escrig, I. Celades, L. Guerra, G. Busani, A. Sterni, Air quality comparison between two European ceramic tile clusters. Atmospheric Environment 74 (2013) 311-319.

[7] Air quality in Europe - 2012 report. In: http://www.eea.europa.eu/publications/air-quality-in-europe-2012.

[8] A. Csapo, P. Baranyi, A unified terminology for the structure and semantics of CogInfoCom channels, Acta Polytechnica Hungarica, 1(2012) 85-105.

[9] D. Ocenasova, An important tol of environmental policy in Slovakia- integrated pollution prevention and control. Management of Environmet 2013, 13th Conference Proceedings, Strix Zilina, 13(2013), 40-43.

[10] Law No. 318/2012 Coll. of Laws on the Air (in Slovak).

[11] Ministry of Environment Regulation No. 360/2010 Coll. of Laws on the Air Quality Limit Values (in Slovak).

[12] Directive 2008/50/EC on ambient air quality and cleaner air for Europe.

[13] I. Dana, A. Badea, Studies Regarding the Use of Remote Sensing Satellite Data for the Identification of Heavy Metal Pollution in Agri-cultural Fields, Annals of DAAAM for 2011 \& Proceedings, Viena, 22(2011) 0085-0086.

[14] A. Plaia, F. Di Salvo, M. Ruggieri, G. Agro, A multisite-Multipollutant air quality index, Atmospheric Environment, 70(2013) 387-391.

[15] P. Hebak, Multivariate statistical methods 3 (in Czech), Informatorium Praha, 2007.

[16] M. Despotović-Zrakić, D. Barać, Z. Bogdanovic, B. Jovanic, B. Radenković, Software Environment for Learning Continuous System Simulation, Acta Polytechnica Hungarica, 2 (2014) 187-202.

[17] M. Pazitna, V. Labudová, Methods of statistical comparisons (in Slovak), Ekonom ed. Bratislava, 2007.

[18] I. Stankovicova, M. Vojtkova, Multivariate statistical methods with aplication, IURA Edition, Bratislava, 2007.

[19] A. Catas, C. Dubau, L. Galea.,Mathematical simulation of pollution index, Annals of DAAAM for 2010 \& Proceedings, Viena, 21 (2010). 